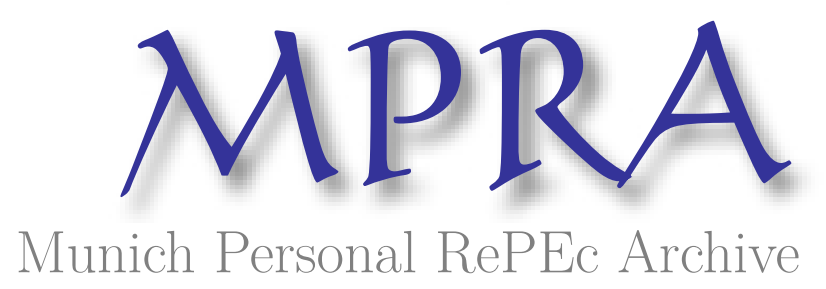

Assessing the appropriateness of zero and negative interest rate regimes: recent developments and comparative analyses

Ojo, Marianne and Newton, Sarah

North West University, Kent University

28 July 2016

Online at https://mpra.ub.uni-muenchen.de/72696/

MPRA Paper No. 72696, posted 31 Jul 2016 04:46 UTC 


\begin{abstract}
This paper explores the widely held theoretical view that zero interest rates should result in lower borrowing costs - propelling the demand for borrowing, "the theory and practice of monetary policy",

against the practical and broader acknowledgements that further negative consequences, namely bank runs - as well as the possibility of the occurrence of concerns of banks becoming more prone to the probabilities of greater unwillingness to lend, could occur. The latter negative consequence of banks' unwillingness to lend, being considered to arise where "banks absorb the cost of negative rates themselves" such that this phenomenon "squeezes" the profit margin between their lending and deposit rates.

However, as will be illustrated, different sources and authorities on the literature agree that it is still too early to draw conclusions on the impact of negative interest rates - be it in respect of i) whether it will work, ii) its wider impact and repercussions for the economy - as well as those economies where the policy has not yet been implemented (even where the policy is on the cards - namely in jurisdictions such as the United States), as well as (iii) its impact on the behavior of individuals (households) and firms.

In exploring the appropriateness of its adoption - given prevailing global financial conditions and the economic environment, the paper also contributes to the extant literature from a theoretical, practical, empirical, as well as comparative jurisdictional perspective.
\end{abstract}

Key Words: interest rates, monetary policy, central banks, market rates, lending rates 


\title{
ASSESSING THE APPROPRIATENESS OF ZERO AND NEGATIVE INTEREST RATE REGIMES: RECENT DEVELOPMENTS AND COMPARATIVE ANALYSES
}

\author{
Marianne Ojo ${ }^{1}$ and Sarah Newton ${ }^{2}$ \\ Introduction and Background to Literature Review
}

The introduction of traditional policies to provide "additional monetary stimulus" in the aftermath of the recent Financial Crisis has been instigated by central banks such as Danmarks Nationalbank (DN), the European Central Bank (ECB), Sveriges Riksbank, the Swiss National Bank (SNB) and more recently, the Bank of Japan. Whilst the European Central Bank, Swiss National Bank, Danmarks Nationalbank and Sveriges Riksbank introduced negative interest rates in mid-2014 and early 2015, the Bank of Japan's more recent introduction is compared to its previous experience of 2006, whose impact is considered relevant from the perspective of the:

- i) Decline of the volume of transactions by about one-half (following three months of the introduction of the policy) - as well as low turn over - up till the end of 2006 when the zero interest rate policy was discontinued.

However, dangers in drawing premature conclusions about the impact of the zero interest rate policy are reflected by remarks such as the "difficulty in disentangling the impact on money market turnover of zero interest rates from other important determinants, such as increased counterparty risk or ample liquidity provision by the central bank, or the uncertain macroeconomic environment that led to the central bank decision in the first place', as well as " the difficulty in isolating the effect of negative policy rates alone" - given the following factors:

- The initial introduction of negative policy rates' coincidence with a decrease in longer maturity and higher-risk yields, although simultaneous central bank asset purchase programmes and;

- other factors behind the fluctuations in the risk premium.

In highlighting and illustrating factors which affect the impact of monetary policy - when the policy rate becomes very negative, Asterlind et al, add that:

- as long as market rates and lending rates continue to fall, the impact will basically be normal. such a development is, however, not sustainable for the banks in the long term. If lending rates continue to follow the policy rate down, the profitability of the banks will sooner or later come under pressure. It is then possible that the banks will start

\footnotetext{
${ }^{1}$ Professor, Faculty of Commerce and Administration, North West University Email:marianneojo@ @otmail.com

${ }^{2}$ Senior Lecturer, Department of Economics, Kent University, Email: sarahjessnewton@ gmail.com
} 
compensating by increasing the margin between the repo rate and lending rates, which will reduce the impact of further policy rate cuts. Eventually, lending rates will stop falling and this will tend to reduce the actual impact of monetary policy even further. The banks might have difficulty lending money to customers when lending rates are frozen, while the market rates continue to fall in line with the repo rate.

\section{CONCLUSION and AREAS TO BE ADDRESSED}

Two further areas highlighted by Cœuré as constituting sources whereby risks could emerge from zero or even negative interest rates are as follows:

- Firstly, money market activity might suffer beyond the trading incentives effect. Important market intermediaries, such as money market funds, could be driven out of business, as their business model loses profitability, for both domestic and foreign investors with excess liquidity may shift their investments to alternative, more profitable market segments;

- secondly, zero or negative interest rates may produce adverse effects on the profitability of commercial banks and financial intermediaries more broadly. In a financial crisis this can result in a credit contraction.

What are the real impacts of negative interest rates? - be it in respect of: i) whether it will work, ii) its wider impact and repercussions for the economy - as well as those economies where the policy has not yet been implemented (even where the policy is on the cards - namely in jurisdictions such as the United States), as well as (iii) its impact on the behavior of individuals (households) and firms.

Are negative interest rates actually more damaging and likely to present greater risks than initially anticipated? Do the overall benefits derived from their adoption far exceed or outweigh the resulting costs - or have certain risks been underestimated? 


\section{References}

Alsterlind, J., Armelius, H., Forsman, D., Jönsson, B., and Anna-Lena Wretman, "How Far Can the Repo Rate be Cut?" Sveriges Riskbank No 112015

http://www.riksbank.se/Documents/Rapporter/Ekonomiska_kommentarer/2015/rap_ek_kom_nr1 1_150929_eng.pdf

Bank of Canada (2015): "Bank of Canada updates framework for unconventional monetary policy measures", press release, 8 December.

Bank for International Settlements (2015): 85th Annual Report, June.

Beck, M., and Malkhozov, A. "How Have Central Banks Implemented Negative Policy Rates?" BIS Quarterly Review, March 2016 https://www.bis.org/publ/qtrpdf/r_qt1603e.pdf

Cœuré., B, "Central Bank and the Challenges of the Zero Lower Bound" Intervention by Benoît Cœuré, Member of the Executive Board of the ECB, at the "Meeting on the Financial

Crisis", hosted by the Initiative on Global Markets, at the University of Chicago Booth School of Business, Miami, 19 February 2012

http://www.ecb.europa.eu/press/key/date/2012/html/sp120219.en.html

Long, J. "Janet Yellen: Negative Rates Possible in US"

http://money.cnn.com/2016/02/11/news/economy/negative-interest-rates-janet-yellen/

Randow, J., and Kennedy, S. "Negative Interest Rates: Less Than Zero” June 62016

http://www.bloomberg.com/quicktake/negative-interest-rates 